\title{
Properties of Photövoltaic Cell using ZnPc/C60 Double Layer Devices
}

\author{
Ho-Sik Lee and Dae Shik Seo \\ Division of Electrical and Electronics, Yonsei University, \\ 134 Shinchon-dong, Seodaemoon-gu, Seoul 120-749, Korea \\ Won Jae Lee \\ Department of Electric Information Engineering, Kyungwon College, \\ Bokjeong-dong, Sujeong-gu, Seongnam-si, Gyeonggi-do 461-702, Korea \\ Kyung Uk Jang \\ Department of Automotive Engineering, Kyungwon College, \\ Bokjeong-dong, Sujeong-gu, Seongnam-si, Gyeonggi-do 461-702, Korea \\ Tae Wan Kim \\ Department of Physics, Hong Ik University, \\ Sangsu-dong, Mapo-gu, Seoul 121-791, Korea \\ Sung II Lee \\ Department of Safety Engineering, Chungju National University, \\ Iryu-myeon, Chungju-si, Chungcheongbuk-do 380-702, Korea \\ ${ }^{a}$ E-mail : gghslee@daum.net
}

(Received March 4 2005, Accepted May 19 2005)

\begin{abstract}
It has been a long time since organic solar cells were expected as a low-cost energy-conversion device. Although practical use of them has not been achieved, technological progress continues. Morphology of the materials, organic/inorganic interface, metal cathodes, molecular packing and structural properties of the donor and acceptor layers are essential for photovoltaic response. We have fabricated solar cell devices based on zinc-phthalocyanine $(\mathrm{ZnPc})$ as donor(D) and fullerene $\left(\mathrm{C}_{60}\right)$ as electron acceptor(A) with doped charge transport layers, and $\mathrm{BCP}$ and $\mathrm{Alq}_{3}$ as an exciton blocking layer(EBL). We have measured the photovoltaic characteristics of the solar cell devices using the Xe lamp as a light source. We were use of $\mathrm{Alq}_{3}$ layer leads to external power conversion efficiency was $2.65 \%$ at illumination intensity $100 \mathrm{~mW} / \mathrm{cm}^{2}$. Also we confirmed the optimum thickness ratio of the DA hetero-junction is about 1:2.
\end{abstract}

Keywords : Photovoltaic cell, EBL, Zinc-phthalocyanine(ZnPc), C60, $\mathrm{Alq}_{3}$

\section{INTRODUCTION}

In recent years, the power conversion efficiencies of thin-film organic photovoltaic(PV) cells has increased steadily and rapidly[1,2]. These improvements have come from the introduction of device concepts such as the donor-acceptor(DA) heterojunction blended and laminated DA heterojunctions, the exciton-blocking layer(EBL), and highly doped crystalline materials. A photovoltaic effect is a way of converting solar radiation into electricity, which was first discovered by
Becquerel[3,4]. These days, a solar power conversion efficiency of monocrystalline silicon solar cell reached up to $24 \%[5]$. However, a production of this kind of inorganic device requires difficult manufacturing processes such as high temperatures as well as numerous lithographic steps.

Most of the small molecules used in organic photovoltaic cells are deposited using thermal evaporation to obtain a desired film thickness. These photovoltaic cells have been intensively studied for the last ten years. In 1986, Tang developed a photovoltaic 
cell using $\mathrm{CuPc} / \mathrm{PV}$ organic materials and obtained a solar power efficiency of about $1 \%$ with corresponding external quantum efficiency of about $30 \%$ [6-8].

Thus, we have studied the photovoltaic effects depending on the photoactive organic layer thickness and EBL. In this paper, we report the photovoltaic effects in the ITO/ZnPc/ $/ \mathrm{C}_{60} / \mathrm{BCP} / \mathrm{Al}$ and $\mathrm{ITO} / \mathrm{ZnPc} / \mathrm{C}_{60} /$ $\mathrm{Alq}_{3} / \mathrm{Al}$ device structure.

\section{EXPERIMENTAL}

The indium-tin-oxide(ITO) glass, having a sheet resistance of $15 \Omega / \square$ was received from Samsung Corning Co. The line patterned ITO glass was cleaned by sonicating it in chloroform for 20 minutes at $50{ }^{\circ} \mathrm{C}$. And then the ITO glass was heated at $80^{\circ} \mathrm{C}$ for 1 hour in solution made with second distilled deionized water, ammonia water and hydrogen peroxide with a volume ratio of $5: 1: 1$. We sonicated the substrate again with a chloroform for 20 minutes at $50{ }^{\circ} \mathrm{C}$ and in deionized water for 20 minutes at $50{ }^{\circ} \mathrm{C}$. After sonicating the substrate, it was dried with $\mathrm{N}_{2}$ gas stream and stored it under vacuum[9].

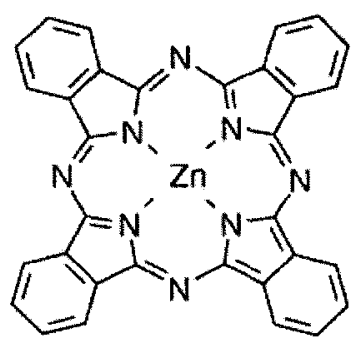

(a) Zinc Phthalocyaine $(\mathrm{ZnPc})$

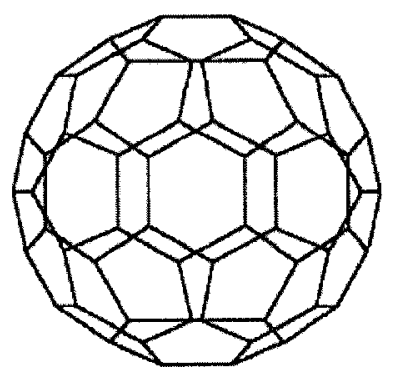

(b) $\mathrm{C} 60$

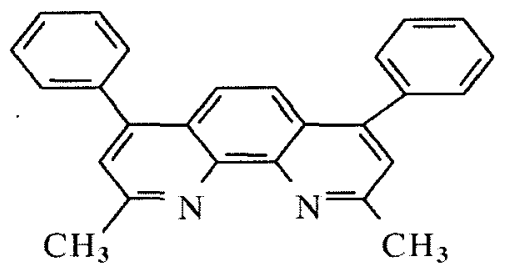

(c) BCP

Fig. 1. Schematic of molecular structure.
Figure 1 shows a schematic of a molecular structure and Fig. 1(a) is, Zinc Phthalocyaine $(\mathrm{ZnPc})$, as an electron acceptor and (b) is C60 as an electron donor and (c) is BCP as an exciton blocking layer(EBL).

Figure 2 shows a schematic structure of photovoltaic cells and energy band diagram of the materials used in our experiment. Double-layered organic photovoltaic cells of ITO/ZnPc/C $60 / \mathrm{EBL} / \mathrm{Al}$ were fabricated to see a correlation between a photovoltaic performance and a $\mathrm{ZnPc}$ layer thickness varied from $10 \mathrm{~nm}$ to $50 \mathrm{~nm}$ made with thermal-vapor deposition at $10^{-6}$ torr. To compare a performance with exciton blocking layer photovoltaic cells, a device structure of $\mathrm{ITO} / \mathrm{ZnPc} / \mathrm{C}_{60} / \mathrm{BCP}\left(\right.$ or $\mathrm{Alq}_{3}$ )/ $\mathrm{Al}$ was also fabricated. The $\mathrm{C}_{60}, \mathrm{BCP}$ and $\mathrm{Alq}_{3}$ layer were also made using thermal evaporation. And $\mathrm{Al}$ cathode $(150 \mathrm{~nm})$ was deposited at $1.0 \times 10^{-6}$ torr using thermal evaporation as well. An active cell area of device was made using a shadow mask to be $3 \mathrm{~mm} \times 5 \mathrm{~mm}$.

Current density-voltage characteristics of organic photovoltaic cells were measured using Keithley 236 source-measure unit and a $500 \mathrm{~W}$ xenon lamp(ORIEL 66021). Light intensity on the device was measured by radiometer/photometer of International Light Inc(IL14004). All measurements were carried out at room temperature.

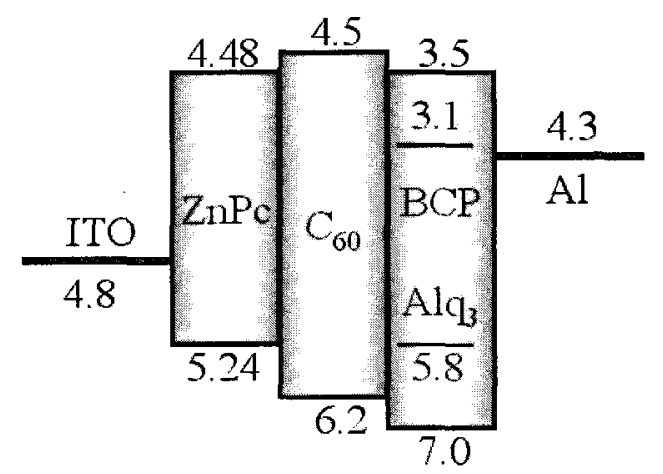

Fig. 2. Schematic the energy band diagram of the PV cell

\section{RESULTS AND DISCUSSION}

Figure 3 shows the current density-voltage characteristics of $\mathrm{ITO} / \mathrm{ZnPc} / \mathrm{C}_{60} / \mathrm{Alq}_{3} / \mathrm{Al}$ and $\mathrm{ITO} / \mathrm{ZnPc} /$ $\mathrm{C}_{60} / \mathrm{BCP} / \mathrm{Al}$ devices when the light is illuminated to the device(Light illumination intensity @ $100 \mathrm{~mW} / \mathrm{cm}^{2}$ ).

From the current density-voltage characteristics under the illumination of light, we can obtain two important parameters, which are $x$ - and $y$-intercept of the curve. One is open-circuit voltage $\mathrm{V}_{\mathrm{OC}}(\mathrm{x}$-intercept) and the other is short-circuit current density $\mathbf{J}_{\mathrm{SC}}(\mathrm{y}$-intercept). So we observed that the optimum thickness ratio of the $\mathrm{ZnPc}: \mathrm{C}_{60}$ layer was $1: 2$.

Figure 4 shows the open-circuit voltage of the two PV cells. It shows that the $\mathrm{V}_{\mathrm{oc}}$ (open-circuit voltage) increases as the illumination intensity increases. The increment rate is higher in PV cell with $\mathrm{Alq}_{3}$ layer. 
Figure 5 shows the shot-circuit current of the two PV cell. The $\mathrm{J}_{\mathrm{sc}}$ (shot-circuit current density) is almost the same in two PV cells with BCP and the $\mathrm{Alq}_{3}$ layer. The fill factor(FF) and the power conversion efficiency(PE) are calculated from the Fig. 3 and Fig. 4, and the FF and $\mathrm{PE}$ equations are the following.
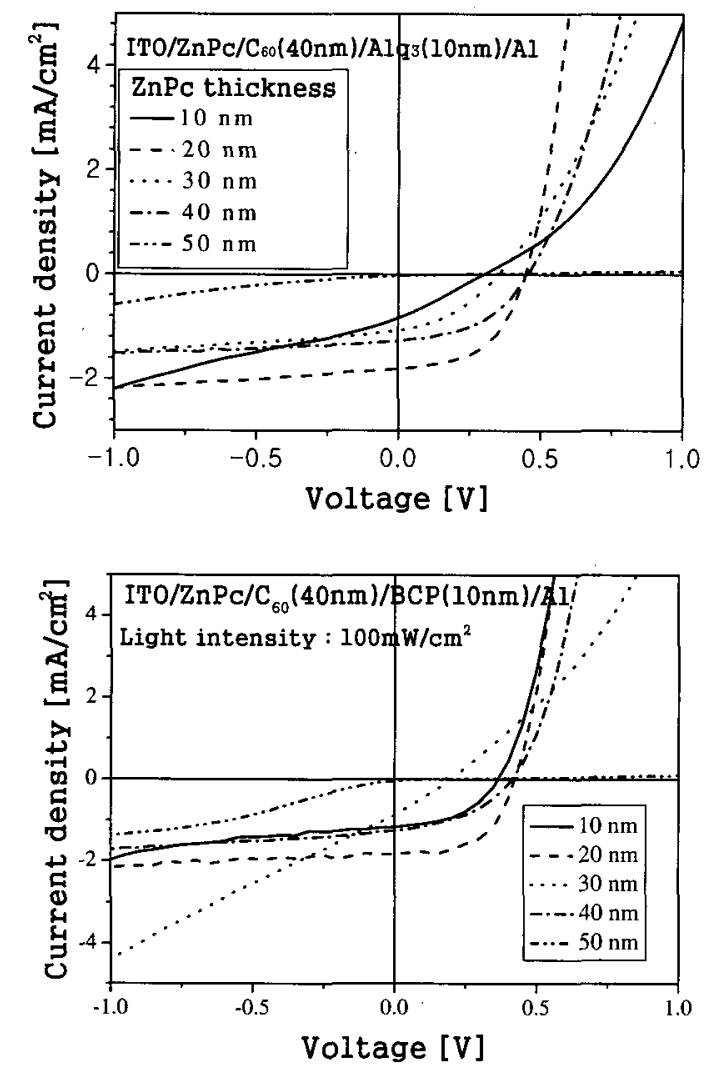

Fig. 3. Current density-voltage characteristics of the ITO $/ \mathrm{ZnPc} / \mathrm{C}_{60} / \mathrm{Alq}_{3} / \mathrm{Al}$ and $\mathrm{ITO} / \mathrm{ZnPc} / \mathrm{C}_{60} / \mathrm{BCP} / \mathrm{Al} \mathrm{de}-$ vices(Light intensity @ $100 \mathrm{~mW} / \mathrm{cm}^{2}$ ).

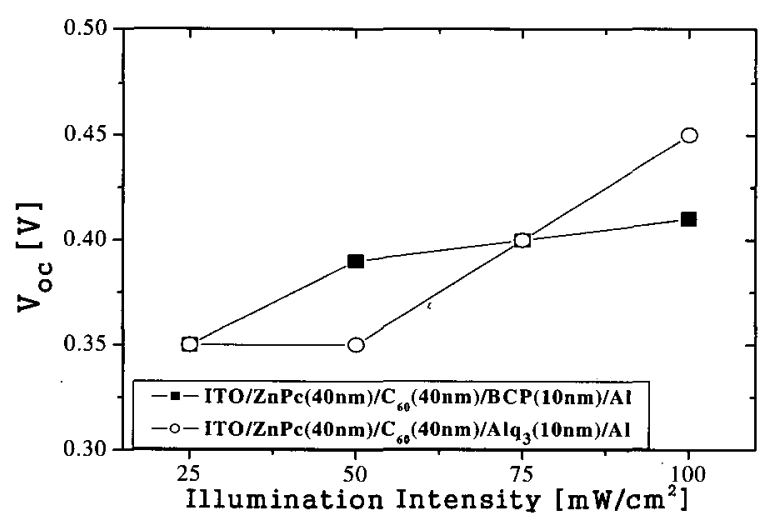

Fig. 4. Open-circuit voltage-illumination intensity characteristics of the two PV cells.

$$
\begin{gathered}
F F=\frac{P_{m}}{V_{O C} \times J_{S C}}=\frac{V_{m} \times J_{m}}{V_{O C} \times J_{S C}} \\
\eta=\frac{P_{m}}{P_{\text {in }}}=\frac{V_{O C} \times J_{S C} \times F F}{I_{0}}
\end{gathered}
$$

Here, $I_{o}$ is the incident solar power.

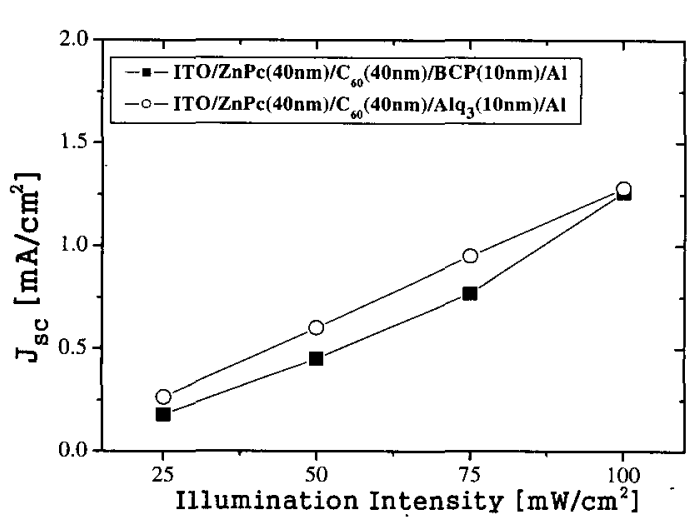

Fig. 5. Short-circuit current density-illumination intensity characteristics of the two PV cells.

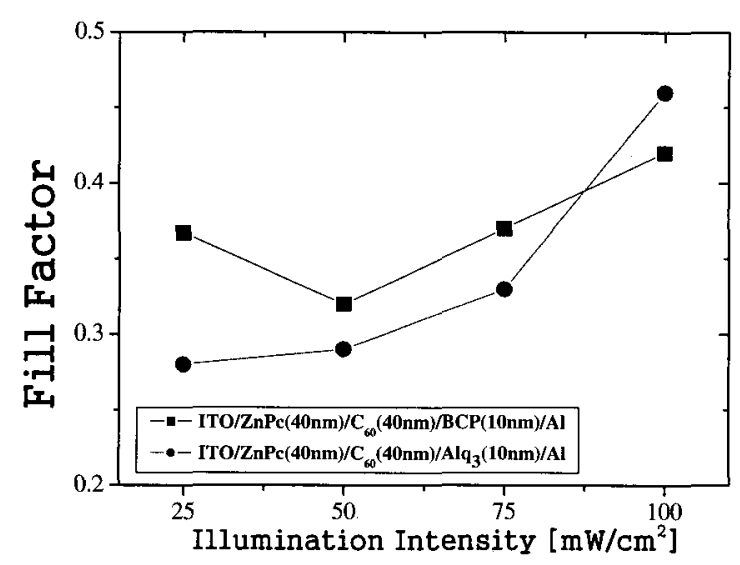

Fig. 6. Fill factor of the two PV cells as a function of illumination intensity.

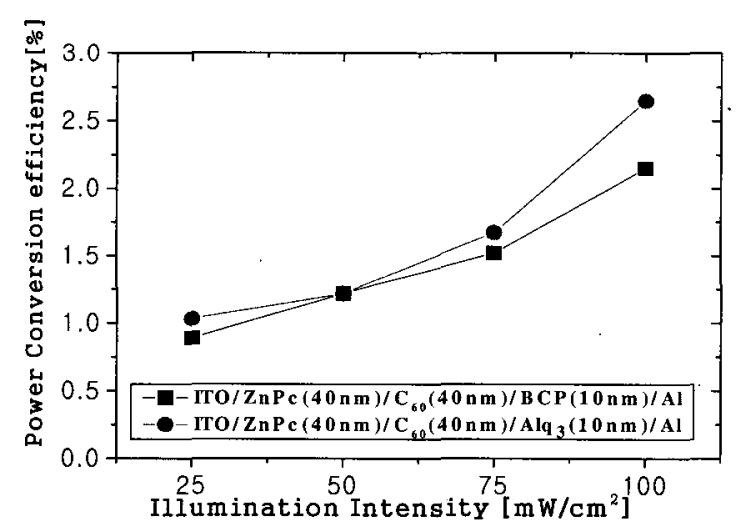

Fig. 7. Power conversion efficiency of the two PV cells as a function of illumination intensity. 
Figure 6 shows the calculated fill factor of the two types PV cell using Eq.[1]. In PV cell with the $\mathrm{Alq}_{3}$, the fill factor is somewhat lower than that with the BCP in the region of illumination intensity from 25 to 75 $\mathrm{mW} / \mathrm{cm}^{2}$. However, when the illumination intensity is $100 \mathrm{~mW} / \mathrm{cm}^{2}$, the fill factor is higher.

Figure 7 shows the power conversion efficiency of the PV cells. The efficiency increases as the illumi-nation intensity increases, especially the PV cell with $\mathrm{Alq}_{3}$ layer is a little bit higher compared to the cell with $\mathrm{BCP}$ layer. Basically, we can say that the efficiency is mainly affected by $\mathrm{ZnPc} / \mathrm{C}_{60}$ layer.

\section{CONCLUSION}

We have seen the electrical properties and photovoltaic properties of the organic solar cells employing an EBL layer. The use of $\mathrm{Alq}_{3}$ layer leads to external power conversion efficiency $(2.65 \%$ at illumination intensity $100 \mathrm{~mW} / \mathrm{cm}^{2}$ ). Also, we confirmed the optimum thickness ratio of the $\mathrm{DA}$ hetero-junction with $\mathrm{ZnPc} / \mathrm{C}_{60}$ layer is about $1: 2$. We are going to further works to introduce the buffer layer between ITO and $\mathrm{ZnPc}$ for improvement of efficiency.

\section{ACKNOWLEDGMENTS}

This work was supported by the Brain Korea 21 Project in 2003.

\section{REFERENCES}

[1] C. W. Tang and S. A. VanSlyke, "Organic electroluminescent diodes", Appl. Phys. Lett., Vol. 51, No. 21, p. 913, 1987.
[2] P. Peumans and S. R. Forrest, "Very-high-efficiency double-heterostructure copper phthalocyanine/C60 photovoltaic cells", Appl. Phys. Lett., Vol. 79, No. 1, p. 126, 2001.

[3] P. Peumans, A. Yakimov, and S. R. Forrest, "Small molecular weight organic thin-film photodetectors and solar cells", J. of Applied Physics, Vol. 93, No. 7 p. $3693,2003$.

[4] H. W. Jung, C. Lee, J. H. Shin, S. H. Shin, and K. J. Park, "Effect of sputtering conditions for CdTe thin films on $\mathrm{CdTe} / \mathrm{CdS}$ solar cell characteristics", J. of KIEEME(in Korean), Vol. 10, No. 9, p. 930, 1997.

[5] S. S. Kim, D. G. Lim, D. Y. Kim, J. M. Kim, C. Y. Won, and J. S. Yi, "Efficiency improvement of polycrystalline silicon solar cells using a grain boundary treatment", J. of KIEEME(in Korean), Vol. 10, No. 10, p. 1034, 1997.

[6] K. J. Kim, B. K. Youn, S. W. Kim, W. T. Kim, and C. S. Huh, "The degradation of EVA for the protection of solar cell by UV-rays irradiation", Proc. 2000 Summer Conf. KIEEME, p. 177, 2000.

[7] P. Peumans, V. Bulovic, and S. R. Forrest, "Efficient photon harvesting at high optical intensities in ultrathin organic double-heterostructure photovoltaic diodes", Appl. Phys. Lett., Vol. 76, No. 19, p. 2650, 2000.

[8] Leif A. A. Pettersson, Lucimara S. Roman, and O. Inganas, "Modeling photocurrent action spectra of photovoltaic devices based on organic thin films", J. of Applied Physics, Vol. 86, No. 1, p. 5564, 1999.

[9] S. W. Hur, H. S. Oh, J. U. Lee, S. I. Lee, W. K. Han, and T. W. Kim, "Organic photovoltaic effects using CuPc and C60 depending on the layer thickness", Proc. 2004 Spring Conf. KIEEME, p. 43, 2004. 